\title{
Investigation of Chlamydiaceae in semen and cauda epididymidis and seroprevalence of Chlamydophila abortus in breeding bulls
}

\author{
Ann-Charlotte Karlsson ${ }^{1,2^{*}}$, Stefan Alenius ${ }^{1}$, Camilla Björkman ${ }^{1}$, Ylva Persson ${ }^{3}$, Stina Englund ${ }^{4}$
}

\begin{abstract}
Background: Reproductive disorders associated with chlamydial infection have been reported worldwide in cattle and there are indications of potential venereal transmission.

Methods: Semen samples from 21 dairy bulls and cauda epididymidis tissue samples from 43 beef bulls were analysed for chlamydial agent by real-time polymerase chain reaction (PCR) including an internal amplification control (mimic). Additionally, presence of antibodies against Chlamydophila (Cp.) abortus among the bulls was investigated with the commercial Pourquier ${ }^{\circledR}$ ELISA Cp. abortus serum verification kit.

Results: No chlamydial agent was detected by PCR in either the semen samples or in the tissue samples. Additionally, no antibodies against $C p$. abortus were detected.

Conclusions: The results suggest that $C p$. abortus is very rare, or absent in Swedish bulls and thus the risk for venereal transmission of chlamydial infection through their semen is low. However, because Chlamydophila spp. infection rates seem to differ throughout the world, it is essential to clarify the relative importance of transmission of the infection through semen on cattle fertility.
\end{abstract}

\section{Background}

Bovine chlamydiosis has been associated with several disease manifestations [1]. Reproductive disorders such as sporadic abortions and reduced fertility, linked with chlamydial infection have been reported from Germany [2,3], Great Britain [4], Italy [5], Japan [6], Switzerland [7], Taiwan [8] and the USA [9]. In Sweden, the incidence of abortion in cows is low. However, reproductive disorders and infertility are major causes of culling but are often difficult to be diagnosed. Chlamydial infection in bulls may be the cause to some of these problems [10]. Experimental studies have shown that the bacteria can be excreted in semen of inoculated bulls and rams [11] and isolation of the agent from semen of naturally infected bulls and rams has been reported [12-14]. The vaginal mucosa in sheep and uterine mucosa in cattle are susceptible to infection $[15,16]$ and transmission of

\footnotetext{
* Correspondence: ann-charlotte.karlsson@vetinst.no
'Division of Ruminant Medicine and Veterinary Epidemiology, Department of

* Correspondence: ann-charlotte.karlsson@vetinst.no
'Division of Ruminant Medicine and Veterinary Epidemiology, Department of Clinical Sciences, Faculty of Veterinary Medicine and Animal Science, Swedish University of Agricultural Sciences (SLU), Box 7054, SE-750 07, Swedish University
Uppsala, Sweden
}

chlamydial agent by experimentally infected semen to heifers and sheep has been demonstrated $[17,18]$.

The two species Chlamydophila (Cp.) abortus and $C p$. pecorum are known to infect cattle and are suggested to be ubiquitous $[9,19]$. Moreover, $C p$. psittaci infections in cattle have been reported $[20,21]$. All three species have been identified in bull semen [22,23]. Cp. abortus is the cause of Ovine Enzootic Abortion (OEA), the major infectious cause of abortion and lamb loss with great economic losses in many sheep-producing countries [24]. Cp. pecorum has foremost been associated with polyarthritis, encephalitis and inapparent intestinal infection, and the impact by $C p$. psittaci in ruminants is yet to be investigated.

Each year about 80 top-ranked performance-tested yearling beef bulls are sold all over Sweden, mainly to pedigree breeders, after six months of testing at the only performance testing station in the country. These performance-tested bulls represent the best-documented beef bulls with the highest impact on the breeding programme in Sweden and are therefore important potential transmitters of Chlamydophila spp. by venereal 
route. Additionally, artificial insemination (AI) is performed yearly on more than $95 \%$ of the approximately 400,000 Swedish dairy cows [25]. As there is a possibility of transmission of Chlamydophila spp. via this route, it is important to determine whether breeding bulls are infected through screening of semen before AI in order to minimize this risk. The aim of this study was to investigate the presence of chlamydial agent in semen and in tissue of cauda epididymidis and to estimate the seroprevalence of $C p$. abortus in Swedish bulls.

\section{Methods}

\section{Animals and samples}

Beef bulls

This study comprises samples from a subset of 166 beef bulls from 124 herds from different parts of Sweden that were taken to the only performance testing station in Sweden in September 2002. On arrival the bulls were approximately six months old. They were divided into groups, based on breed and body weight and placed in ten adjacent semi-outdoor pens under the same roof. The bulls were weighed every second week throughout the testing period (September-March) and at the end of the period, an individual growth index was calculated. Bulls with fast growth rates were sold at livestock auction and bulls with growth indexes below the threshold, stated by the breeders' organisations, were either slaughtered or returned to their owners. In total, 43 of the beef bulls that were sent to slaughter were included in this study (23 Charolaise, 7 Hereford, 6 Simmental, 3 Aberdeen Angus, 3 Limousine and 1 Blonde d'Aquitaine). The daily growth rates of these bulls were somewhat lower than the bulls sold at auction, but were still higher than the growth rates of non-tested beef sires in Sweden [26]. Because of co-operation with another study and their definite criteria [27], only bulls with clinically normal reproductive organs and scrotal circumference above $30 \mathrm{~cm}$ were included.

Testes and epididymides were removed at the time of slaughter and immediately put in a container with crushed ice and transported refrigerated to the laboratory where they arrived the next day. An incision (approx. 1.5 $\mathrm{cm}$ long and $0.5 \mathrm{~cm}$ deep) was made with a scalpel blade in the middle, distal part of the cauda epididymides [28], and a sample of $0.5 \times 0.5 \mathrm{~cm}$ was taken and stored at $-70^{\circ} \mathrm{C}$ until used for DNA preparation. In addition, blood samples for serum preparation were taken on arrival (6 month of age) and at departure (1 year of age) from the testing station. Sera were stored at $-20^{\circ} \mathrm{C}$.

\section{Dairy bulls}

Semen samples ( $0.2 \mathrm{ml}$ payettes) and sera from 21 dairy bulls about 1 year old (Swedish Holstein and Swedish Red) in service, were submitted to the laboratory from one of the only two semen producing companies in
Sweden, Svensk Avel http://www.vikinggenetics.com. Semen samples were stored at $-70^{\circ} \mathrm{C}$ prior to preparation for analysis by real-time polymerase chain reaction (PCR). Sera for serology were stored at $-20^{\circ} \mathrm{C}$ until analysed.

\section{Detection of Chlamydiaceae by real-time polymerase chain reaction}

DNA was extracted from semen and cauda epididymidis samples for PCR analysis using a High Pure Template Preparation kit, following manufacturer's instructions (Roche Diagnostics, Basel, Switzerland) and stored at $-20^{\circ} \mathrm{C}$. Analyses were performed using a Chlamydiaceaespecific real-time PCR protocol developed by Everett and others [29], targeting the 23S ribosomal DNA. Briefly, the primers used were TQF (5'-GAA AAG AAC CCT TGT TAA GGG AG-3') and TQR (5'-CTT AAC TCC CTG GCT CAT CAT G-3'). The sequence of the fluorescent FAM-labelled probe was 5'-CAA AAG GCA CGC CGT CAA C-3'.

An internal amplification control (mimic) was constructed and used to detect false negative PCR results, as previously described [30]. The primers used in the mimic producing PCR were TQFActin (5'-GAA AAG AAC CCT TGT TAA GGG AGC CAT GTA CCC TGG CAT TG-3') and TQRActin (5'-CTT AAC TCC CTG GCT CAT CAT GGA TCC ACA CGG AGT ACT TGC-3'). The sequence of the ROX-labelled mimic probe used in real-time PCR was 5'-CCG ACA GGA TGC AGA AGG AGA TCA-3'.

The $25-\mu$ PCR mixture comprised $2.5 \mu \mathrm{l}$ of $10 \times$ PCRbuffer II (Applied Biosystems, Foster City, CA, USA), $2.5 \mathrm{mM} \mathrm{MgCl} 2,0.2 \mathrm{mM}$ of each of the four dNTP, 0.15 $\mu \mathrm{M}$ of each of the primer TQF and TQR, $0.25 \mu \mathrm{l}(1.25$ $\mathrm{U})$ of AmpliTaq Gold DNA polymerase (Applied Biosystems), and $0.1 \mu \mathrm{M}$ of each probe. Reaction mixtures were placed in a Rotor-Gene 3000 (Corbett Research, Cambridge, UK) and amplification was performed according to the protocol of Everett and others [29]. The results were analysed with the Rotor-Gene software version 5.0.

The sensitivity of the PCR was estimated to one inclusion forming unit (IFU) per PCR by spiking semen and tissue samples prior to DNA extraction with ten-fold dilutions of $C p$. abortus (inactivated strain S26/3 in original concentration of $3 \times 10^{8} \mathrm{IFU} / \mathrm{ml}$, kindly provided by D. Longbottom, Moredun Research Institute, UK).

\section{Detection of antibodies to $\mathrm{Cp}$. abortus}

For detection of antibodies the Pourquier ELISA Chlamydophila abortus serum verification kit (Montpellier, France) was applied. The ELISA uses a recombinant fragment of an 80-90 $\mathrm{kDa}$ polymorphic outer membrane protein and detects antibodies against $C p$. abortus. The assay was used according to the manufacturer's instruction with $\mathrm{S} / \mathrm{P} \%$ values $\geq$ than 100 as positive for cattle. 


\section{Results}

All 21 semen and 43 cauda epididymidis samples were negative in the PCR. The internal amplification control (mimic) worked well for all samples analysed.

None of the 21 and 43 paired-sera from dairy and beef bulls, respectively, were positive in the antibody detection assay. Most samples were clustered well below the cut-off value 100 . Only six samples had S/P\% above 20, where 42 was the highest value.

\section{Discussion}

In this study we found no presence of chlamydial agent in any semen or cauda epididymidis tissue samples, i.e. all samples were negative by real-time PCR. This is in concordance with an Austrian study [31] where neither $C p$. abortus nor $C p$. pecorum was detected in 273 semen samples from bulls at five AI centres. On the other hand, the results contradict those reported from other investigations performed in apparently healthy bulls. In Lithuania as much as $29.8 \%$ of 47 tested bulls had chlamydial agent in their semen, as judged by PCR [13], and chlamydiae were detected by immunofluorescence in $14.3 \%$ of 42 bovine ejaculates from the Czech republic [32]. In German and Swiss investigations of semen samples, $9.2 \%$ and $6.6 \%$, respectively, were found positive by PCR $[22,23]$.

The sensitivity of the PCR assay was estimated to 1 IFU per PCR with no indication of potential inhibitory factors. In a previous investigation of cows from dairy herds with reproductive disorders we identified positive specimens, including vaginal swabs, placenta and milk when using the same PCR assay [33]. Moreover, several positive specimens from different organs in pigs and placentae in sheep (unpublished data) as well as conjunctival and nasal swabs from cats [34] have been demonstrated by the same PCR at our laboratory. Those samples were handled and stored in a similar way as in the present study. Therefore, the test is considered robust and to have a high sensitivity and specificity.

All sera were negative in the $C p$. abortus ELISA assay with values far below the cut-off value. The specificity of the test has been reported to be $100 \%$ when used to analyse Scottish sheep documented free of $C p$. abortus [35] and 90\% when sera from New Zealand, a country free from $C p$. abortus, were analysed [36]. The sensitivity were estimated to $91 \%$ and $80 \%$, respectively, when analysing sera from experimentally $C p$. abortus infected sheep $[35,36]$., and it can, hence, not be excluded that some of our sera were positives but not detected by the test. However, the fact that all the beef bulls, which came from as many as 124 different herds from all over Sweden, were still seronegative after they had been housed together for six months, in adjacent pens under the same roof, indicates that $C p$. abortus is not present in Swedish beef cattle herds. Moreover, the absence of seropositives among the analysed dairy bulls indicates that $C p$. abortus is very rare, or absent, in Swedish bulls. These results are in agreement with a previous study in Swedish dairy cows where only 2 out of 525 sera were positive in the same ELISA and only $C p$. pecorum were confirmed in vaginal swabs [33].

\section{Conclusions}

This study suggest the risk for venereal transmission of chlamydial infection through Swedish bull semen is low. However, because Chlamydophila spp. infection rates seem to differ throughout the world, it is essential to clarify the relative importance of transmission of the infection through semen on cattle fertility.

\section{Acknowledgements}

The authors wish to thank Maj Hjort at the National Veterinary Institute (SVA), for performing the serological analyses and for assistance with the DNA preparations. This study was supported by the Swedish Farmer's Foundation for Agricultural Research and the Programme for Infection Biology at the Faculty of Veterinary Medicine and Animal Science, Swedish University of Agricultural Sciences. It was part of the EU research collaboration COST 855.

\section{Author details}

${ }^{1}$ Division of Ruminant Medicine and Veterinary Epidemiology, Department of Clinical Sciences, Faculty of Veterinary Medicine and Animal Science, Swedish University of Agricultural Sciences (SLU), Box 7054, SE-750 07, Uppsala, Sweden. ${ }^{2}$ Department of Animal Health, Section for Farm Animal Health and Welfare, National Veterinary Institute, Pb 750 Sentrum, N-0106 Oslo, Norway. ${ }^{3}$ Department of Animal Health and Antimicrobial Strategies, Section of Farm animals, National Veterinary Institute (SVA), SE-751 89, Uppsala, Sweden. ${ }^{4}$ Department of Animal Health and Antimicrobial Strategies, Section of Antibiotics, National Veterinary Institute (SVA), SE-751 89, Uppsala, Sweden.

\section{Authors' contributions}

ACK participated in the design and coordination of the study, drafted and rewrote the manuscript, carried out the PCR and interpreted the results. SE implemented the PCR systems, constructed the mimic and interpreted the results. CB and SA participated in the design and coordination of the study. YP sampled and wrote about the beef bulls. All authors have been involved in revising the manuscript.

\section{Competing interests}

The authors declare that they have no competing interests.

Received: 14 December 2009

Accepted: 13 January 2010 Published: 13 January 2010

\section{References}

1. Storz J: Overview of animal diseases induced by chlamydial infections. Microbiology of Chlamydia Barron, AL. Florida: CRC Press, Inc 1988, 167-192.

2. Wehrend A, Failing K, Hauser B, Jager C, Bostedt H: Production, reproductive, and metabolic factors associated with chlamydia seropositivity and reproductive tract antigens in dairy herds with fertility disorders. Theriogenology 2005, 63:923-930.

3. Wittenbrink MM, Schoon HA, Bisping W, Binder A: Infection of the bovine female genital tract with Chlamydia psittaci as a possible cause of infertility. Reprod Dom Anim 1993, 28:129-136.

4. Holliman A, Daniel RG, Parr JG, Griffiths PC, Bevan BJ, Martin TC Hewinson RG, Dawson M, Munro R: Chlamydiosis and abortion in a dairy herd. Vet Rec 1994, 134:500-502. 
5. Cavirani S, Cabassi CS, Donofrio G, De laco B, Taddei S, Flammini CF: Association between Chlamydia psittaci seropositivity and abortion in Italian dairy cows. Prev Vet Med 2001, 50:145-151.

6. Nabeya M, Kaneko K, Ogino H, Nakabayashi D, Watanabe T, Murayama J, Hayashi K, Fukushi H, Yamaguchi T, Hirai K, Inaba Y, Matumoto M: Abortion in Japanese cows caused by Chlamydia psittaci. Vet Microbiol 1991, 29:261-265.

7. Pospischil A, Thoma R, von Bomhard W, Reitt K, Cantieni J, Zimmermann DR, Polkinghorne A: [Abortion in cattle caused by Chlamydia psittaci]. Schweiz Arch Tierheilkd 2002, 144:467-472.

8. Wang Fl, Shieh H, Liao YK: Prevalence of Chlamydophila abortus infection in domesticated ruminants in Taiwan. J Vet Med Sci 2001, 63:1215-1220.

9. Kaltenboeck B, Hehnen H-R, Vaglenov A: Bovine Chlamydophila spp. infection: do we underestimate the impact on fertility?. Vet Res Comm 2005, 29:1-15.

10. Storz J, Carroll EJ, Ball L, Faulkner LC: Isolation of a psittacosis agent (Chlamydia) from semen and epididymis of bulls with seminal vesiculitis syndrome. Am J Vet Res 1968, 29:549-555.

11. Storz J, Carroll EJ, Stephenson EH, Ball L, Eugster AK: Urogenital infection and seminal excretion after inoculation of bulls and rams with chlamydiae. Am J Vet Res 1976, 37:517-520.

12. Amin AS: Comparison of polymerase chain reaction and cell culture for the detection of Chlamydophila species in the semen of bulls, buffalobulls, and rams. Vet J 2003, 166:86-92.

13. Domeika M, Ganusauskas A, Bassiri M, Fröman G, Mårdh P-A: Comparison of polymerase chain reaction, direct immunofluorescence, cell culture and enzyme immunoassay for the detection of Chlamydia psittaci in bull semen. Vet Microbiol 1994, 42:273-280.

14. Gautam R, Purohit VD: Isolation of Chlamydia psittaci from genitalia of healthy exotic and crossbred service rams. Indian Journal of Animal Sciences 2001, 71:731-734

15. Papp JR, Shewen PE: Pregnancy failure following vaginal infection of sheep with Chlamydia psittaci prior to breeding. Infect Immun 1996, 64:1116-1125.

16. Wittenbrink MM, Schoon HA, Schoon D, Mansfeld R, Bisping W: Endometritis in cattle experimentally induced by Chlamydia psittaci. Zentralb/ Veterinarmed B 1993, 40:437-450.

17. Appleyard WT, Aitken ID, Anderson IE: Attempted venereal transmission of Chlamydia psittaci in sheep. Vet Rec 1985, 116:535-538.

18. Bowen RA, Spears P, Storz J, Deidel GE Jr: Mechanisms of infertility in genital tract infections due to Chlamydia psittaci transmitted through contaminated semen. J Infect Dis 1978, 138:95-98.

19. DeGraves FJ, Gao D, Hehnen HR, Schlapp T, Kaltenboeck B: Quantitative Detection of Chlamydia psittaci and C. pecorum by High-Sensitivity Real-Time PCR Reveals High Prevalence of Vaginal Infection in Cattle. J Clin Microbiol 2003, 41:1726-1729.

20. Borel N, Thoma R, Spaeni P, Weilenmann R, Teankum K, Brugnera E, Zimmermann DR, Vaughan L, Pospischil A: Chlamydia-related abortions in cattle from Graubunden, Switzerland. Vet Pathol 2006, 43:702-708.

21. Cox HU, Hoyt PG, Poston RP, Snider TG, Lemarchand TX, O'Reilly KL: Isolation of an avian serovar of Chlamydia psittaci from a case of bovine abortion. J Vet Diagn Invest 1998, 10:280-282.

22. Kauffold J, Henning K, Bachmann R, Hotzel H, Melzer F: The prevalence of chlamydiae of bulls from six bull studs in Germany. Anim Reprod Sci 2007, 102:111-121.

23. Teankum K, Pospischil A, Janett F, Brugnera E, Hoelzle LE, Hoelzle K, Weilenmann R, Zimmermann DR, Gerber A, Polkinghorne A, Borel N: Prevalence of chlamydiae in semen and genital tracts of bulls, rams and bucks. Theriogenology 2007, 67:303-310.

24. Aitken ID: Chlamydial abortion. Diseases of Sheep Edinburgh: BlackwellMartin WB, Aitken ID , 3 2000, 81-86

25. SJV: Number of cattle in December 2004. Swedish official statistics 2004, JO 23 SM 0501

26. Eriksson S: Genetic aspects of calving, growth, and carcass traits in beef cattle. PhD thesis Swedish University of Agricultural Sciences, Department of Animal Breeding and Genetics 2003.

27. Persson Y: Breeding Soundness Evaluation of Young Beef Bulls. PhD thesis Swedish University of Agricultural Sciences, Department of Clinical Sciences 2007.
28. Gustafsson B, Crabo B: Some morphological characteristics of bull spermatozoa at different levels of the epididymis. Nord Vet Med 1971 23:114-118.

29. Everett KDE, Hornung $\sqcup$, Andersen $A A$ : Rapid detection of the Chlamydiaceae and other families in the order Chlamydiales: three PCR tests. J Clin Microbiol 1999, 37:575-580.

30. Englund S, Bolske G, Ballagi-Pordany A, Johansson KE: Detection of Mycobacterium avium subsp. paratuberculosis in tissue samples by single, fluorescent and nested PCR based on the IS900 gene. Vet Microbiol 2001, 81:257-271.

31. Petit T, Spergser J, Aurich J, Rosengarten R: Examination of semen from bulls at five Austrian artificial insemination centres for chlamydiae and mollicutes. Vet Rec 2008, 162:792-3.

32. Veznik Z, Pospisil L, Svecova D, Kummer V, Canderle J, Diblikova I, Maskova J: Chlamydiae in reproductive disorders and pathology of reproductive organs in man and animals. Reprod Dom Anim 1996, 31:595600

33. Godin AC, Björkman C, Englund S, Johansson KE, Niskanen R, Alenius S: Investigation of Chlamydophila spp. in dairy cows with reproductive disorders. Acta Vet Scand 2008, 50:39.

34. Bölske G, Ström Holst B, Stillesjö A, Englund S: Detection of Chlamydiaceae in Swedish cats with a real-time PCR with internal control. Diagnosis, pathogenesis and control of animal Chlamydioses. The fourth annual workshop of COST Action 855, Animal Chlamydioses and Zoonotic Implications: 3-5 September 2006; Edinburgh Meigle Colour Printers LtdLongbottom D, Rocchi M 2006, 74-75.

35. Vretou E, Radouani F, Psarrou E, Kritikos I, Xylouri E, Mangana O: Evaluation of two commercial assays for the detection of Chlamydophila abortus antibodies. Vet Microbiol 2007, 123:153-161.

36. McCauley LM, Lancaster MJ, Young P, Butler KL, Ainsworth CG: Comparison of ELISA and CFT assays for Chlamydophila abortus antibodies in ovine sera. Aust Vet J 2007, 85:325-328.

doi:10.1186/1751-0147-52-2

Cite this article as: Karlsson et al.: Investigation of Chlamydiaceae in semen and cauda epididymidis and seroprevalence of Chlamydophila abortus in breeding bulls. Acta Veterinaria Scandinavica 2010 52:2.

\section{Publish with Bio Med Central and every scientist can read your work free of charge}

"BioMed Central will be the most significant development for disseminating the results of biomedical research in our lifetime. "

Sir Paul Nurse, Cancer Research UK

Your research papers will be:

- available free of charge to the entire biomedical community

- peer reviewed and published immediately upon acceptance

- cited in PubMed and archived on PubMed Central

- yours - you keep the copyright
BioMedcentral 